\title{
IN REMEMBRANCE OF THE SAINTS
}


TRANSLATIONS FROM THE ASIAN CLASSICS

Editorial Board:

Paul Anderer

Allison Busch

David Lurie

Rachel McDermott

Wei Shang

Haruo Shirane 


\section{IN REMEMBRANCE OF THE SAINTS}

The Rise and Fall of an Inner Asian Sufi Dynasty

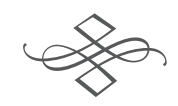

MuHaAMMAD ȘAdIQ KASHGHARI

TRANSLATED BY DAVID BROPHY

Columbia University Press

New York 


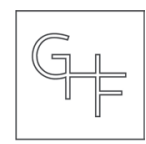

GEISS HSU

FOUNDATION

This publication was made possible in part by an award from the James P. Geiss and Margaret Y. Hsu Foundation.

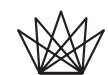 \\ Columbia University Press \\ Publishers Since 1893 \\ New York Chichester, West Sussex \\ cup.columbia.edu \\ Copyright $\odot 2021$ Columbia University Press \\ All rights reserved
}

Library of Congress Cataloging-in-Publication Data

Names: Kāshgharī, Muḥammad Șadiq, active 1780, author. |

Brophy, David John, translator.

Title: In remembrance of the saints : the rise and fall of an Inner Asian Sufi dynasty

/ Muhammad Șadiq Kashghari ; Translated by David Brophy.

Other titles: Tazkira-yi 'azīzān. English

Description: New York City : Columbia University Press, 2020.|

Series: Translations from the Asian classics |

Includes bibliographical references and index.

Identifiers: LCCN 2020028800 (print) | LCCN 2020028801 (ebook) |

ISBN 9780231198189 (hardback) | ISBN 9780231198196 (trade paperback) |

ISBN 9780231552523 (ebook)

Subjects: LCSH: Sufis-Xinjiang Uygur Zizhiqu (China)-Biography. |

Sufism-Xinjiang Uygur Zizhiqu (China)-History. | Naqshabandiyah-Asia,

Central-History. | Xinjiang Uygur Zizhiqu (China)-History.

Classification: LCC BP189.7.N35 K4513 2020 (print) | LCC BP189.7.N35 (ebook) |

DDC 297.4/8-dc23

LC record available at https://lccn.loc.gov/2020028800

LC ebook record available at https://lccn.loc.gov/2020028801

Columbia University Press books are printed on permanent and durable acid-free paper.

Printed in the United States of America

Cover image: Section of a genealogical scroll of the

Naqshbandi Sufis of Xinjiang, circa 1800.

Cover design: Milenda Nan Ok Lee 